\title{
Crisis Self-Efficacy and Work Commitment of Education Workers among Public Schools during COVID-19 Pandemic
}

\author{
Erick T. Baloran ${ }^{1}$ and Jenny T. Hernan ${ }^{2}$ \\ ${ }^{1,2}$ University of Mindanao - Bansalan College, Bansalan, Davao del Sur, Philippines
}

\begin{abstract}
COVID-19 pandemic has affected the public educational sectors in terms of adjustment in educational modalities of instructional delivery, school operations, and policies. With this emerging paradigm shift, teachers' crisis self-efficacy and work commitment are relevant for research. This study's main objective was to determine the significant influence of crisis self-efficacy on the work commitment of public school teachers in Region XI (Davao Region), Philippines, during the COVID-19 pandemic. The sample consisted of 1,340 public school teachers across the Davao Region. The researchers collected the data through adapted questionnaires contextualized to the local setting and administered through online Google forms with appended consent. Mean, standard deviation, Pearson $r$, and regression analysis were used to analyze data. Results revealed that crisis self-efficacy significantly influences the work commitment of public school teachers during the COVID-19 pandemic. Uncertainty management during this crisis, in particular, best predicts teachers' work commitment. Data also showed a high level of crisis self-efficacy in terms of action, preventive, achievement and uncertainty management, and high level of teachers' work commitment in terms of commitment to school, commitment to students, commitment to teaching, and commitment to profession. Correlation results also showed a link between crisis self-efficacy and the work commitment of teachers amid pandemic. Finally, the study concluded with practical recommendations and directions for future research.
\end{abstract}

Keywords: crisis self-efficacy, work commitment, education workers, public schools, COVID19 pandemic

\section{Introduction}

The COVID-19 pandemic has affected educational systems worldwide, leading to the near-total closures of schools, universities, and colleges. Most governments around the world have temporarily closed educational institutions to contain the spread of the virus. These nationwide closures are impacting over $60 \%$ of the world's student population. Several other countries have implemented localized closures affecting millions of additional learners [38]. Studies on the impact of the COVID-19 pandemic were conducted in the Philippines, which not just clearly revealed strong reactions among students but also discovered teachers' level of anxiety amid school closures. However, Filipino teachers' positive outlook amid psychological stress or anxiety was seen. Teachers indeed had to face work and life changes during the pandemic situation. Moreover, teachers face challenges with the online-blended learning approach as they embrace the new normal in teaching. Schools are still challenged to fill the gaps 
in providing Information and Communication Technology (ICT) resources and capacities of both teachers and students as they embrace the paradigm shift in pedagogical delivery [2] [25] [33]. Relatively, the work commitment of the organization's employees in the midst crisis like a pandemic may be affected. When an emergency occurs within an organization, it usually disrupts daily activities. It can generate fear of financial loss, and its impact to the organization could be immediate or long-term [26] [28].

In the school context, teachers' work commitment during the COVID-19 crisis is important. Teachers needed to abruptly transition their lessons from physical classrooms to distance learning platforms in response to this crisis. Though they are struggling with many challenges in their efforts to meet the development needs of their students, they remain committed to their learners' education and emotional, social, cognitive, physical, and spiritual well-being. Stories abound teachers' concern for their students' mental health, and other personal and academic concerns [23] [24]. Furthermore, evidence-backed strategies are needed to help ensure teachers' well-being and maintain their commitment to work during the COVID-19 pandemic. Teachers need to develop adaptability in which they can adjust their thoughts, actions, and emotions to navigate new, changing, or uncertain situations effectively. Since the teaching profession amid crisis involves many unexpected situations and events, teachers must respond to the changing needs of students throughout a lesson, adapt to manage unexpected situations relating to student behavior, and make adjustments to their teaching plans when timetable changes occur [7] [18]

Besides, during a crisis like this, teachers must demonstrate greater commitment to their job and consequently increase their engagement at work [8] [9]. With or without a pandemic crisis, commitment is an essential element of successful teaching. Showing commitment to student learning, especially in this pandemic time can be an important factor in motivating students to continue school. Committed teachers recognize and endeavor to fulfill their responsibilities to their students. The degree of loyalty of committed teachers have, toward their profession is one of their distinguished characters. Teachers who are engaged in their profession and committed to students and their learning play a crucial role in the development of students [17]. One factor which influences the work commitment, especially during a crisis, is the selfefficacy beliefs. Employees with high efficacy beliefs perceive crises and dilemmas as challenges. They are highly committed to the work tasks they carry out and invest more time and 
effort into their work activities. They also think strategically to resolve problems, recover easily from predicaments, feel they are in control of the majority of stressors and are less vulnerable to stress and depression [5]. These concepts have led many researchers to conclude that, in general, high levels of self-efficacy relate to positive and desired results [30] [32]. In particular, crisis self-efficacy is a predictor of individual behavior in crises [27]. In the teachers' perspective, teachers' self-efficacy beliefs are positively related to their commitment to the teaching profession [6].

As Philippines combat against the COVID-19 pandemic, the Department of Education (DepEd) started to brace for the new normal in education amid the pandemic situation in the country. DepEd conducted a nationwide consultation with stakeholders and education experts and prepared for a Learning Continuity Plan to deliver education to learners. In preparation for School Year 2020-2021, DepEd will provide Self-Learning Modules (SLMs) with the alternative learning delivery modalities for various types of learners across the Philippines, including modular, television-based, radio-based instruction, blended, and online. SLMs are delivered in printed format to schools located in coastal areas, far-flung provinces, and communities without access to the internet or electricity. For households with gadgets and devices, the department has announced that SLMs can also be accessed online or offline. The department also assured that teachers' safety and health will be its top priority as SLMs can be done at home. Teachers who would need to visit their schools to get materials to prepare the SLMs are required to follow the existing work arrangement and health protocols [11]. With this existing scenario, public school teachers indeed need to adapt to this emerging shift in the paradigm of teachers. Teachers have to adapt with the increasing demand of their workloads in preparation for the opening of classes in the new normal pedagogical setting. Hence, this situation calls for their crisis self-efficacy and, consequently, develops their commitment to work and profession as educators. Furthermore, the researchers had not come across of the study that dealt with the influence crisis self-efficacy on the work commitment of public school teachers during the COVID-19 pandemic in the local setting. In this context, the researchers were interested in determining the domain of crisis selfefficacy, which significantly predicts the work commitment of public school teachers in Region XI, Philippines. This study can raise concern to beneficiaries of this study and possibly develop action plans to improve teachers' self-efficacy and consequently augment their work commitment during a crisis such as a pandemic, thus, the need to conduct this study. The following research 
objectives guide this study: describe the level of crisis self-efficacy of public school teachers in terms of action, preventive, achievement, and uncertainty management; ascertain the level of work commitment of public school teachers during the COVID-19 pandemic in terms commitment to school, commitment to students, commitment to teaching, and commitment to profession; determine the significance of the relationship between the crisis self-efficacy and work commitment of public school teachers during COVID-19 pandemic, and determine the domain of crisis self-efficacy which best predicts teachers' work commitment.

\section{Methods}

Quantitative, non-experimental design of research using the correlational technique was used in this study since it aimed to determine the significant relationship between the crisis selfefficacy and work commitment of public school teachers during the COVID-19 pandemic. The venue of the study was in Region XI, located in Mindanao, Philippines. The region is composed of five provinces, namely: Davao del Sur, Davao Oriental, Davao del Norte, Davao de Oro and Davao Occidental with six cities namely: Davao City, Digos City, Tagum City, Panabo City, Mati City and the Island Garden City of Samal. An online survey developed through Google forms with an appended consent form was conducted from May 30 - June 11, 2020. During this period, the Philippines experienced the first wave of sustained community transmission, and provinces in Davao Region were under General and Enhanced Community Quarantine set by the

local governments. The Snowball technique was used to determine the teacher respondents who had access to the internet. The Survey link was disseminated to various public school divisions both in the elementary and secondary levels. Adapted survey questionnaires were used for crisis self-efficacy [26] and work commitment [34]. They were modified to suit the purpose of the study, especially during the COVID-19 pandemic period. A total of 1,340 public school teachers across the region responded in the online survey.

Data were analyzed using mean, standard deviation, Pearson r, and regression analysis as statistical tools to interpret the collated data. The following range of means with its descriptions was used: $1.00-1.79$ (Very Low); 1.80 - 2.59 (Low); 2.60 - 3.39 (Moderate); 3.40 - 4.19 (High); 4.20 - 5.00 (Very High). The corresponding interpretation for each range starts from never to rarely, sometimes, oftentimes, and always manifested for every item in the questionnaire. The researchers personally administered the collection of data. Data collection 
was done after proper permission was sought from the concerned authorities and entities. Encoding, tabulation, and data analysis were thoroughly done to assure the quality of the entire study. Ethics was thoroughly observed in the study's conduct, considering the respondent's participation in the online survey was voluntary.

\section{Results and discussion}

Examining the data in descriptive table 1 on the levels of the crisis self-efficacy and work motivation of public school teachers during COVID-19 pandemic, it could be noted that the standard deviation of the mean scores ranged from 0.472 to 0.891 which are all below 1.0 , the typical standard deviation for a 5 point Likert scale. This indicates the consistency of responses.

Table 1

Level of Crisis Self-Efficacy and Work Commitment of Public School Teachers in Region XI, Philippines during COVID-19 Pandemic

\begin{tabular}{clcl}
\hline Variables/Indicators & $\begin{array}{l}\text { Standard } \\
\text { Deviation }\end{array}$ & $\begin{array}{c}\text { Mean } \\
\bar{x}\end{array}$ & $\begin{array}{l}\text { Descriptive } \\
\text { Level }\end{array}$ \\
\hline Crisis Self-Efficacy & $\mathbf{0 . 6 8 1}$ & $\mathbf{3 . 8 7}$ & high \\
Action & 0.819 & 3.94 & high \\
Preventive & 0.722 & 3.91 & high \\
Achievement & 0.766 & 3.85 & high \\
Uncertainty Management & 0.751 & 3.76 & high \\
Work Commitment & $\mathbf{0 . 5 6 8}$ & $\mathbf{3 . 9 7}$ & high \\
Commitment to school & 0.688 & 4.06 & very high \\
Commitment to students & 0.708 & 4.23 & high \\
Commitment to teaching & 0.687 & 4.17 & high \\
Commitment to profession & 0.472 & 3.40 & \\
\hline
\end{tabular}

Data revealed that the high level of crisis self-efficacy of public school teachers during COVID-19 pandemic $(\overline{\mathrm{x}}=3.7$; SD $=0.681)$ among public schools in Region XI, Philippines (Table 1) is the result of the high mean rating of its indicators: action, preventive, achievement, and uncertainty management ranging from 3.76 to 3.94 as evaluated by the teacher respondents. High level means that the crisis self-efficacy of public school teachers during the COVID-19 pandemic is oftentimes manifested.

Further, data implies that teachers take the necessary action to protect them at work during the COVID-19 crisis. They also use their knowledge and personal and work resources to 
prevent problems brought about by the pandemic effectively. Amid the health crisis, public school teachers still set to accomplish individual and work-related goals, especially facing tasks and responsibilities upon implementing distance and blended learning modalities in teaching. Fortunately, teachers during the COVID-19 crisis can manage uncertainties effectively. They feel confident and resourceful in handling unforeseen and unexpected demands at work. As professed by one author [27], crisis self-efficacy enables crisis organizational members and leaders to develop more effective message strategies to protect everyone and minimize crisis damage. Besides, another study [14] mentioned that having a high level of action efficacy could help prevent employees from additional or unnecessary harm. One research finding [21] also argued that enough information and resources as part of preventive efficacy lead to certainty in crisis. Employees with higher levels of certainty are likely to be prevented from more dangerous situations during an emergency. When facing a current crisis, employees need to constitute desirable work goals and increase self-belief that they could stick to and achieve goals during the crisis [26]. Moreover, several authors [22] [29] [37] stated that managing uncertainty is essential for crisis management.

Moreover, the overall high level of work commitment of public school teachers during COVID-19 pandemic $(\overline{\mathrm{x}}=3.97$; $\mathrm{SD}=0.568)$, as reflected in Table 1 , is the result of the high mean scores of its indicators: commitment to school, commitment to teaching, and commitment to profession, with mean scores ranging from 3.40 to 4.17 and only one very high rating $(\overline{\mathrm{x}}=$ 4.23) of the indicator commitment to students. The high level of work commitment of public school teachers during the COVID-19 pandemic is an indication that teachers among public schools in the region maintained a strong commitment to delivering quality education for students despite the health crisis the community is facing.

As the data shows, teachers are committed to fulfilling their functions and proactively implement the educational policies of the Department of Education (DepEd) during the COVID19 pandemic. They feel committed and obliged to ensure academic success and continuous learning of students amid the health crisis through varied ways such as distance learning, blended learning, home-based learning, etc. To cope with these current problems and dilemmas brought by the pandemic crisis, teachers remain to be goal-oriented by planning and strategizing a flexible mode of instructional delivery. Also, teachers professed that despite the new normal condition in school, they still feel enjoyed and committed to their profession. They feel engaged 
in fulfilling the teaching mission despite the challenging changes in the paradigm of teaching amid the COVID-19 crisis. In support, education during the pandemic is not an easy task. Teachers need to face continuous changes in educational needs such as pedagogy, curriculum, and regulatory educational policies. Since teachers are facing challenges [16], they should invest more effort and involvement in maintaining and promoting high-quality teaching and optimizing student outcomes [10]. The level of effort and involvement exerted by the teachers in pursuit for quality of teaching are reflected by their continued commitment to work, school, students, and to profession [12] [35]. Furthermore, commitment to students motivates teachers to deal with students undergoing personal crises or to be more sensitive and aware of student development and their achievement [13] [15]. Also, teachers' commitment to teaching is reflected through their willingness to exert effort in providing effective instruction and devote extra time to students [36]. Likewise, teachers who are highly committed to their school are expected to engage in school tasks to achieve the school goals despite the existing circumstances [31]. According to some authors [20], employees need to choose to redirect their emotional energies toward the profession to which they belong despite work conditions. Generally, during a crisis, teachers must demonstrate a more significant commitment to their job and consequently increase their engagement at work [8] [9].

One important purpose of this study was to determine whether or not crisis self-efficacy has a significant relationship with public school teachers' work commitment during the COVID19 pandemic. As shown in table 2, the overall r-value on the correlation between the level of crisis self-efficacy and the level of work commitment of public school teachers during COVID19 pandemic is .615 with the $\mathrm{p}<0.01$ which means that there is a significant relationship between the two variables, thus rejecting the null hypothesis. Generally, the correlation between the two variables revealed a significant relationship between the crisis self-efficacy and the work commitment of public school teachers during the COVID-19 pandemic. It implies that the crisis self-efficacy is significantly linked to teachers' work commitment during a pandemic. Further, it concludes that public school teachers display a high level of commitment at work in the COVID19 crisis due to their high level of crisis self-efficacy. Teachers maintain high efficacy beliefs that recognize crisis as part of their work dilemmas and are highly committed to fulfilling work tasks at school, especially to their learners' education. It confirmed the proposition of various authors [30] [32] that work commitment, especially during a crisis, is linked with self-efficacy 
beliefs. Employees with high efficacy beliefs, who perceive crises and dilemmas as challenges, are highly committed to the work tasks they carry out.

Table 2

Significance on the Relationship between the Crisis Self-Efficacy and Work Commitment of Public School Teachers in Region XI, Philippines during COVID-19 Pandemic

\begin{tabular}{lccccc}
\hline \multirow{2}{*}{$\begin{array}{l}\text { Crisis Self- } \\
\text { Efficacy }\end{array}$} & $\begin{array}{c}\text { Commitment } \\
\text { to School }\end{array}$ & $\begin{array}{c}\text { Commitment } \\
\text { to Students }\end{array}$ & $\begin{array}{c}\text { Commitment } \\
\text { to Teaching }\end{array}$ & $\begin{array}{c}\text { Commitment } \\
\text { to Profession }\end{array}$ & Overall \\
\hline Action & $.513^{* *}$ & $.435^{* *}$ & $.451^{* *}$ & $.346^{* *}$ & $.499^{* *}$ \\
& $(.000)$ & $(.000)$ & $(.000)$ & $(.000)$ & $(.000)$ \\
Preventive & $.548^{* *}$ & $.485^{* *}$ & $.530^{* *}$ & $.402 * *$ & $.561^{* *}$ \\
& $(.000)$ & $(.000)$ & $(.000)$ & $(.000)$ & $(.000)$ \\
Achievement & $.560^{* *}$ & $.493^{* *}$ & $.524 * *$ & $.342^{* *}$ & $.552^{* *}$ \\
Uncertainty & $(.000)$ & $(.000)$ & $(.000)$ & $(.000)$ & $(.000)$ \\
Management & $.582^{* *}$ & $.520^{* *}$ & $.559 * *$ & $.368^{* *}$ & $.584 * *$ \\
Overall & $(.000)$ & $(.000)$ & $(.000)$ & $(.000)$ & $(.000)$ \\
& $.618^{* *}$ & $.542^{* *}$ & $.578^{* *}$ & $.408^{* *}$ & $.615^{* *}$ \\
\hline
\end{tabular}

**. Correlation is significant at the 0.01 level

In addition, data shown in Table 3 is the regression coefficients to test the significant influence of the overall crisis self-efficacy on the work commitment of public school teachers during the COVID-19 pandemic. Using the regression analysis, the data revealed that teachers' overall crisis self-efficacy significantly influences their work commitment during the COVID-19 pandemic since statistical data showed has the $F$ value 208.49 and $p<0.01$. Hence, it signifies the rejection of null hypothesis. The R2 value of .384 implies that their crisis self-efficacy influenced $38.40 \%$ of the variance of work commitment of public school teachers during the COVID-19 pandemic. In comparison, the remaining $61.60 \%$ was attributed to other factors. Specifically, in their singular capacities, the domains of teachers' crisis self-efficacy such as preventive $(\mathrm{T}=4.785 ; \mathrm{p}<0.01)$, achievement $(\mathrm{T}=3.792 ; \mathrm{p}<0.01)$, and uncertainty management $(\mathrm{T}=6.529 ; \mathrm{p}<0.01)$ have a significant influence on their work commitment during the COVID19 pandemic. On the other hand, the domain action $(\mathrm{T}=2.363 ; \mathrm{p}=0.018)$ can still influence teachers' work commitment but with the support of other domains. Furthermore, among the domains of teachers' crisis self-efficacy, uncertainty management is the best predictor of their 
work commitment during COVID-19 pandemic in its singular capacity based on the standardized beta coefficients $(\beta=.266)$.

Table 3

Regression Analysis on the Influence of Crisis Self-Efficacy on the Work Commitment of Public School Teachers in Region XI, Philippines during COVID-19 Pandemic

\begin{tabular}{lcccc}
\hline \multicolumn{5}{c}{ Work Commitment } \\
\hline Crisis Self-Efficacy & $\begin{array}{c}\boldsymbol{\beta} \\
\text { (Standardized } \\
\text { Coefficients) }\end{array}$ & $\begin{array}{c}\text { B } \\
\text { (Unstandardized } \\
\text { Coefficients) }\end{array}$ & T & p-value \\
\hline Action & .082 & .057 & 2.363 & .018 \\
Preventive & .192 & .151 & 4.785 & .000 \\
Achievement & .146 & .109 & 3.792 & .000 \\
Uncertainty Management & .266 & .202 & 6.529 & .000 \\
$\mathbf{R}$ & .620 & & & \\
$\mathbf{R}^{2}$ & .384 & & & \\
F & 208.49 & & & \\
Overall $\boldsymbol{p}$-value & .000 & & & \\
\hline
\end{tabular}

The above data revealed that the overall crisis self-efficacy significantly influences the work commitment of public school teachers during the COVID-19 pandemic. It affirmed the proposition [8] self-efficacy beliefs under any circumstances influence work commitment. In conjunction, the finding of this study substantiated the study [6], which pointed out that teachers' self-efficacy beliefs influence their commitment to the teaching profession. Moreover, among the four domains of teachers' crisis self-efficacy, the uncertainty management domain is the best predictor of teachers' work commitment during the COVID-19 pandemic in its singular capacity based on the standardized beta coefficients. It implies that teachers' ability to manage or reduce uncertainties at work and in teaching during the COVID-19 crisis contributes to their high commitment to providing continuous and quality education for students. They are still committed to achieving school and professional goals despite the crisis. They feel capable of controlling and 
adjusting with the unforeseen or unexpected changes in work conditions, especially in the aspect of pedagogy. In connection with this finding, a related study [26] stated that managing uncertainty is essential for crisis management. Crisis management must minimize uncertainty before a crisis occurs as well as manage uncertainties that emerge during a crisis. Considering that uncertainty management efficacy reflects one's beliefs about the ability to deal with uncertainty in crises, reducing the amount of uncertainty before a crisis occurs would result in a higher level of uncertainty management efficacy among employees, and thus contributing to higher work commitment.

\section{Conclusion and recommendations}

In today's world health condition where the teachers in the public educational sectors are challenged in terms of adjusting with the paradigm shift of teaching and learning process, improving crisis self-efficacy is essential for maintaining and augmenting teachers' commitment at work. Results revealed that crisis self-efficacy significantly influences the work commitment of public school teachers during the COVID-19 pandemic. Uncertainty management, in particular, best predicts teachers' work commitment during this crisis. Teachers' high efficacy belief in effectively managing unforeseen circumstances at work caused by the pandemic is a predictor of their high commitment to fulfil their professional and pedagogical functions and responsibilities in school. Further, results specifically revealed a high level of crisis self-efficacy in terms of action, preventive, achievement and uncertainty management, and high level of work commitment of public school teachers during COVID-19 pandemic in terms of commitment to school, commitment to students, commitment to teaching, and commitment to profession. Correlation results also showed a link between crisis self-efficacy and the work commitment of teachers amid pandemic. In this study, a clear picture is established on the role of self-efficacy of work employees who deem themselves as capable of managing crises resulting in maintaining and supporting work commitment. Also, this study vividly emphasized the importance of teachers' work commitment during the COVID-19 crisis. With the immediate transition at work, such as shifting from physical classroom contact to distance and online, blended modality, teachers need to remain committed to delivering accessible and quality education for all learners across the cultural, social, economic, and geographical backgrounds. 
As the results showed that uncertainty management in crisis self-efficacy is a significant predictor of teachers' commitment at work during COVID-19 pandemic, the researchers highly recommend for the Department of Education to initiate programs which focus on improving the uncertainty management skills of its human resources especially the teachers when facing a crisis in the community and at work. Teachers should be trained on how to be agile and adaptive to unexpected changes in work settings. This can be done at the school community level with the help and support of school administrators and colleagues. Various school-based activities and established resiliency systems and practices can be organized to develop teachers' strategies in making themselves change-proof. With these, teachers can also effectively cope with school organizational uncertainty and the personal upheaval that it causes during any crisis, such as the COVID-19 pandemic.

Moreover, as teachers face structural uncertainty amid pandemic or any present calamities such as in the area teaching and technological change, and the rapidly changing nature of work, it is recommended for DepEd to begin to retool teachers with the new modalities for school operations and instruction. It is also recommended that the Department train school administrators and teachers on how to reduce organizational uncertainties during a crisis. School employees need to increase their motivation to reduce uncertainty in the workplace when confronting risky social situations. Teachers, in particular, should adapt overt and covert techniques to mitigate certain types of organizational uncertainty. In these times of significant change in the educational set-up brought by the COVID-19 pandemic, DepEd should improve information dissemination, awareness campaign, and policy implementation to decrease uncertainty levels of teachers among schools. The researchers also recommend for every school leader in helping teachers reinvent their professional commitment by providing mental and psychological interventions to reduce possible psychosocial morbidity experienced by teachers, especially during the period of sustained community quarantine. School-level activities may be organized to fortify teachers' commitment to choosing the teaching profession and maintain pride and engagement in fulfilling the mission of their job despite the challenging changes in the paradigm of teaching with or without the COVID-19 crisis.

Moreover, since the study stated the significant relationship between the crisis selfefficacy and work motivation of public school teachers during the COVID-19 pandemic, it is highly recommended that teachers take preventive actions at work by augmenting their 
knowledge and personal and job resources. With this, teachers can effectively attain the department's educational targets despite work uncertainties, especially in implementing distance and blended learning modalities in teaching during the COVID-19 crisis. Schools can improve teachers' crisis self-efficacy by developing more effective message strategies to safeguard teachers, parents, students, and stakeholders and minimize the risks of COVID-19 in the educational system. Lastly, the researchers would like to suggest to future researchers that a similar study with a more significant number of samples may be conducted in another venue to confirm the elimination of the results as generated in this study.

Author Contributions: Conceptualization, E.B.; Data curation, E.B., and J.H.; Methodology, E.B., and J.H.; Software, E.B.; Writing — original draft, E.B..; Writing-review \& editing, E.B., and J.H. All authors have read and agreed to the published version of the manuscript.

Acknowledgments: Data of this study were collected with the assistance of the Planning and Research Unit of the Department of Education (DepEd) - Davao de Oro and other divisions in Davao Region, Philippines. We thank all DepEd personnel for cooperating in this personally funded research.

Conflicts of Interest: The authors declare no conflict of interest.

\section{References}

1. Ashford, J. B., \& LeCroy, C. W. (2010). Human behavior in the social environment: A multidimensional perspective (4th ed.). CA: Wadsworth, Cengage Learning.

2. Baloran, E.T. (2020). Knowledge, attitudes, anxiety, and coping strategies of students during COVID-19 pandemic, Journal of Loss and Trauma, DOI: 10.1080/15325024.2020.1769300.

3. Bandura, A. (1977). Self-efficacy: The exercise of control. New York, NY: W. H. Freeman and Company.

4. Bandura, A. (1986). Social foundations of thought and action. Englewood Cliffs, NJ: Prentice-Hall.

5. Bandura, A. (2008). Social cognitive theory. In W. Donsbach, (Ed.) International encyclopedia of communication (Vol. 10, pp. 4654-4659). Oxford, UK: Blackwell.

6. Chesnut, S., \& Burley, H. (2015). Self-efficacy as a predictor of commitment to the teaching profession: A meta-analysis. Educational Research Review, 15, 1-16.

7. Collie, R. J., \& Martin, A. J. (2016). Adaptability: An important capacity for effective teachers. Educational Practice and Theory, 38(1), 27-39.

8. Collie, R. J., \& Martin, A. J. (2017). Teachers' sense of adaptability: Examining links with perceived autonomy support, teachers' psychological functioning, and students' numeracy achievement. Learning and Individual Differences, 55, 29-39. 
9. Collie, R. J., Martin, A.J. \& Granziera, H. (2018, May 8). Being able to adapt in the classroom improves teachers' well-being. The Conversation. Retrieved from https://theconversation.com/being-able-to-adapt-in-the-classroom-improves-teacherswell-being-9578.

10. Darling-Hammond, L., \& McLaughlin, M. W. (1995). Policies that support professional development in an era of reform. PhiDelta Kappan, 76, 597-604.

11. Department of Education (2020). DepEd prepares Self-Learning Modules for education's new normal. Retrieved from https://www.deped.gov.ph/2020/07/02/deped-prepares-selflearning-modules-for-educations-new-normal/.

12. Firestone, W. A. (1996). Images of teaching and proposals for reform: A comparison of ideas from cognitive and organizational research. Educational Administration Quarterly, 32, 209-235.

13. Firestone, W. A., \& Pennell, J. R. (1993). Teacher commitment, working conditions, and differential incentive policies. Review of Educational Research, 63, 489-525.

14. Frisby, B. N., Veil, S. R., \& Sellnow, T. L. (2014). Instructional messages during healthrelated crises: Essential content for self-protection. Health Communication, 29, 347-354.

15. Louis, K. S. (1998). Effects of teacher quality of work life in secondary schools on commitment and sense of efficacy. School Effectiveness and School Improvement, 9, 127.

16. Louis, K. S., \& Smith, B. (1990). Teacher working conditions. In P. Reyes (Ed.), Teachers and their workplace: Commitment, performance and productivity (pp. 23-47). Newbury Park, CA: SAGE.

17. Mart, C. T. (2013). A passionate teacher: Teacher commitment and dedication to student learning. International Journal of Academic Research in Progressive Education and Development, 2(1), 437-442.

18. Martin, A. J., Nejad, H., Colmar, S., \& Liem, G. A. D. (2012). Adaptability: Conceptual and empirical perspectives on responses to change, novelty and uncertainty. Journal of Psychologists and Counsellors in Schools, 22(1), 58-81.

19. Meyer, J. P., \& Herscovitch, L. (2001). Commitment in the workplace: Toward a general model. Human Resources Review, 11(3), 299-326. doi:10.1016/s1053-4822(00)00053-x.

20. Meyer, J. P., Allen, N. J., \& Topolnytsky, L. (1998). Commitment in a changing world of work. Canadian Psychology/Psychologie Canadienne, 39, 83-93.

21. Moynihan, D. P. (2008). Learning under uncertainty: Networks in crisis management. Public Administration Review, 68(2), 350-365.

22. Murphy, P. (1996). Chaos theory as a model for managing issues and crises. Public Relations Review, 22, 95-113.

23. Olson, K. (2020, May 7). Tips for teachers in a pandemic. Retrieved from https://www.redlands.edu/bulldog-blog/2020/april-2020/tips-for-teachers-in-a-pandemic/. 
24. O'Sullivan, M. (2020, May 1). What about teachers' learning during COVID-19? Retrieved from https://www.wise-qatar.org/what-about-teachers-learning-during-covid$19 /$.

25. Pan, H. (2020). A glimpse of university students' family life amidst the COVID-19 virus. Journal of Loss and Trauma, 1 -4. https://doi.org/10.1080/15325024.2020.1750194.

26. Paraskevas, A. (2006). Crisis management or crisis response system? Management Decision, 44 (7), 892-907.

27. Park, S. (2016). Development and validation of a crisis self-efficacy scale. Retrieved from https://trace.tennessee.edu/utk_graddiss/3661.

28. Ren, C. (2000).Understanding and managing the dynamics of linked crisis events. Disaster Prevention and Management, 9(1), 12-17.

29. Reynolds, B., \& Seeger, M. W. (2005). Crisis and emergency risk communication as an integrative model. Journal of Health Communication, 10, 43-55.

30. Salanova, M., Schaufeli, W.B., Xanthopoulou, D., \& Bakker, A. (2009). The gain spiral of resources and work engagement. In A. Bakker \& M. Leiter (Eds.) Work engagement: recent developments in theory and research. New York: Psychology Press.

31. Somech, A., \& Bogler, R. (2002). Antecedents and consequences of teacher organizational and professional commitment. Educational Administration Quarterly, 38, 555-577.

32. Stajkovic, A., \& Luthans, F. (1998). Self-efficacy and work-related performance: a metaanalysis. Psychological Bulletin, 124, 240-261.

33. Talidong, K.J.B., \& Toquero, C.M.D. (2020). Philippine teachers' practices to deal with anxiety amid COVID-19. Journal of Loss and Trauma, DOI: 10.1080/15325024.2020.1759225.

34. Thien, L.M., Razak, N.A., \& Ramayah, T. (2014). Validating Teacher Commitment Scale Using a Malaysian Sample. SAGE Open, 1-9. DOI: 10.1177/2158244014536744.

35. Tsui, K. T., \& Cheng, Y. C. (1999). School organisational health and teacher commitment: A contingency study with multi-level analysis. Educational Research and Evaluation, 5, 249-268.

36. Tyree, A. K. (1996). Conceptualising and measuring commitment to high school teaching. Journal of Educational Research, 89, 295-304.

37. Ulmer, R. R., Seeger, M. W., \& Sellnow, T. L. (2007). Post-crisis communication and renewal: Expanding the parameters of post-crisis discourse. Public Relations Review, 33, 130-134.

38. UNESCO (2020). Education: From disruption to recovery. Retrieved from https://en.unesco.org/covid19/educationresponse. 